\title{
The Effect of Particle Size of Wollastonite Filler on Thermal Performance of Intumescent Fire Retardant Coating
}

\author{
M. Zia-ul-Mustafa, ${ }^{1, a}$, Faiz Ahmad ${ }^{1}$, Puteri S.M. Megat-Yusoff ${ }^{1}$ and Hammaz Aziz ${ }^{1}$ \\ ${ }^{1}$ Department of Mechanical Engineering, Universiti Teknologi PETRONAS, Malaysia
}

\begin{abstract}
Intumescent Fire retardant coatings (IFRC's) are one of the simplest ways to protect substrates exposed to fire. In this study, Wollastonite (W) filler of two different particle sizes were used to determine the fire performance of intumescent fire retardant coating. The basic ingredients of the coating were ammonium poly-phosphate (APP) as acid source, expandable graphite (EG) as carbon source, melamine (MEL) as blowing agent in epoxy binder, boric acid as additive and hardener as curing agent. A series of coating formulations were developed by using different weight percentages of both sized Wollastonite fillers. The coated steel substrate samples were tested for fire performance using Bunsen burner and char expansion was measured using furnace fire test. A Comparison of the coatings thermal performance was determined. Wollastonite containing filler particle size $10 \mu \mathrm{m}$ showed better thermal performance than formulations containing filler's particle size $44 \mu \mathrm{m}$.
\end{abstract}

\section{Introduction}

The usage of structural steel in construction of buildings is increasing day by day due to its excellent strength. Factory buildings, commercial buildings, multistory car parks, offshore constructions, aircrafts and transport industry involve the foremost applications of structural steel. The protection of steel structure has become necessary in all construction industries in many countries all over the world $[1,2]$. Steel material is of great interest for architects owing to its ability to tolerate high temperature [3]. However the loadbearing ability of steel decreases to half of its original strength beyond the temperature of $550^{\circ} \mathrm{C}$ [4]. Intumescent coating is a passive fire protection system, which is used to save steel in case of fire [5]. However, it does not change the intrinsic properties of the material (e.g. the mechanical properties) [6].

IFRC's form multicellular char structure on the surface of the polymeric materials to protect the material from flame $[7,8]$. This char acts as physical barrier to heat transfer and oxygen transmission [8]. IFRC's are formulated to perform under severe conditions so that steel can maintain its integrity from one to three hours, when the temperature of the surroundings increases up to $1100^{\circ} \mathrm{C}$ [2].

The objective of this study was to compare the effect of particle size of wollastonite filler on thermal performance of intumescent fire retardant coatings. Wollastonite filler has a higher melting point (around $1540^{\circ} \mathrm{C}$ ) which can withstand higher temperature $[9,10]$. Wollastonite has also been used as thermal stabilizer in propylene composites [11]. A good synergy of Wollastonite with APP in polystyrene has been observed to increase thermal performance of polystyrene [12].

\footnotetext{
${ }^{\text {a }}$ Corresponding author : engr.ziamustafa@gmail.com
}

This is an Open Access article distributed under the terms of the Creative Commons Attribution License 2.0, which permits unrestricted use, distribution, and reproduction in any medium, provided the original work is properly cited. 


\section{Materials and Method}

Ammonium Poly Phosphate (APP) was purchased from Clariant (Malaysia) Sdn Bhd. Bisphenol A epoxy resin BE-I88 (BPA) was used as a binder with Hardener H-2310 polyamide amine was purchased from Mc-Growth chemical Sdn. Bhd. Malaysia. Melamine (Mel) was used as blowing agent and Boric Acid (BA) was used as an additive purchased from Sigma-Aldrich (Malaysia) Sdn Bhd. EG was used as carbonaceous source. Wollastonite was bought from Hebei Yunsong Trade Co., Ltd. China. Filler particle size of $10 \mu \mathrm{m}$ and $44 \mu \mathrm{m}$ were used to make formulation showed in table 1 individually.

\subsection{Sample Preparation}

Cleaning of steel surface provides good adhesion of the coating with the surface. Steel surface was sand blasted to remove unwanted dust materials from the surface. Sand blasting also provides necessary surface roughness by creating crests and troughs in the surface. Surface roughness provides good adhesion between the coating material and the substrate.

Table 1 Compositions of Formulations [wt. \%]

\begin{tabular}{|c|c|c|c|c|c|c|c|}
\hline No & EG & APP & Mel & Boric Acid & Epoxy & Hardener & Filler \\
\hline IFR & 5.8 & 11.76 & 5.76 & 11.5 & 43.42 & 21.71 & 0 \\
\hline IFR1 & 5.8 & 11.76 & 5.76 & 11.5 & 42.76 & 21.38 & 1 \\
\hline IFR2 & 5.8 & 11.76 & 5.76 & 11.5 & 42.1 & 21 & 2 \\
\hline IFR3 & 5.8 & 11.76 & 5.76 & 11.5 & 41.42 & 20.71 & 3 \\
\hline IFR4 & 5.8 & 11.76 & 5.76 & 11.5 & 40.76 & 20.38 & 4 \\
\hline IFR5 & 5.8 & 11.76 & 5.76 & 11.5 & 40.16 & 20.09 & 5 \\
\hline
\end{tabular}

\subsection{Coating development and application}

Accurately measured amounts of coatings ingredients were mixed using shear mixer at 20rpm on room temperature. All solid ingredients were mixed with epoxy for $20 \mathrm{mins}$ and in last $10 \mathrm{mins}$, hardener was added in mixture. Coating was applied on steel plates using conventional brush coating technique. The applied coating was allowed to cure for two days.

\section{Results and Discussion}

\subsection{Bunsen burner Fire Test}

To measure the thermal performance of Intumescent Fire retardant coatings (IFRC's) on laboratory scale Bunsen burner fire test was conducted according to UL-94 standards. 60mins fire test was 
performed and substrate backside temperature was recorded after every min using Anarittsu Data logger, Input Channel 6 Model AM-8000K. Formulations IFR5 and IFR4 containing wollastonite filler particle size $44 \mu \mathrm{m}$ gave substrate temperature $153^{\circ} \mathrm{C}$ and $174{ }^{\circ} \mathrm{C}$ respectively after $60 \mathrm{mins}$ fire test. While the formulations IFR2 and IFR3 containing wollastonite particle size $10 \mu \mathrm{m}$ showed substrate backside temperature of $138^{\circ} \mathrm{C}$ and $121^{\circ} \mathrm{C}$ respectively.

\subsection{Expansion of Char}

To examine the physical properties of char such as char expansion and char structure after fire test, the IFRC's were burned in finance to develop char in a Carbolite Furnace. IFR4 containing filler particle size $44 \mu \mathrm{m}$ showed expansion 4.9 times and IFR5 gave 5 times expansion than original thickness. But IFRC's IFR4 containing filler particle size $10 \mu \mathrm{m}$ showed expansion of 5 times and $5 \mathrm{wt} \%$ showed expansion of 6.2 times of the original thickness. So smaller filler particle size showed more char expansion compared to larger particle size in IFRC's.

\subsection{Field Emission Scanning Electron Microscopy (FESEM)}

FESEM results at higher magnification honey comb like structure observed. Figure1 (c) IFR5 for $10 \mu \mathrm{m}$ particle size showed average pore size $7.7 \mu \mathrm{m}$ and Figure1(a) IFR5 for 44um particle size showed average pore size of $11.5 \mu \mathrm{m}$, which resulted smaller particle size develop smaller pore size and fewer gases are escaped from char and increasing expansion of char and provide barrier of heat from source to substrate. These small pores help to entrap incombustible gases during fire, increasing the thermal performance of the char.
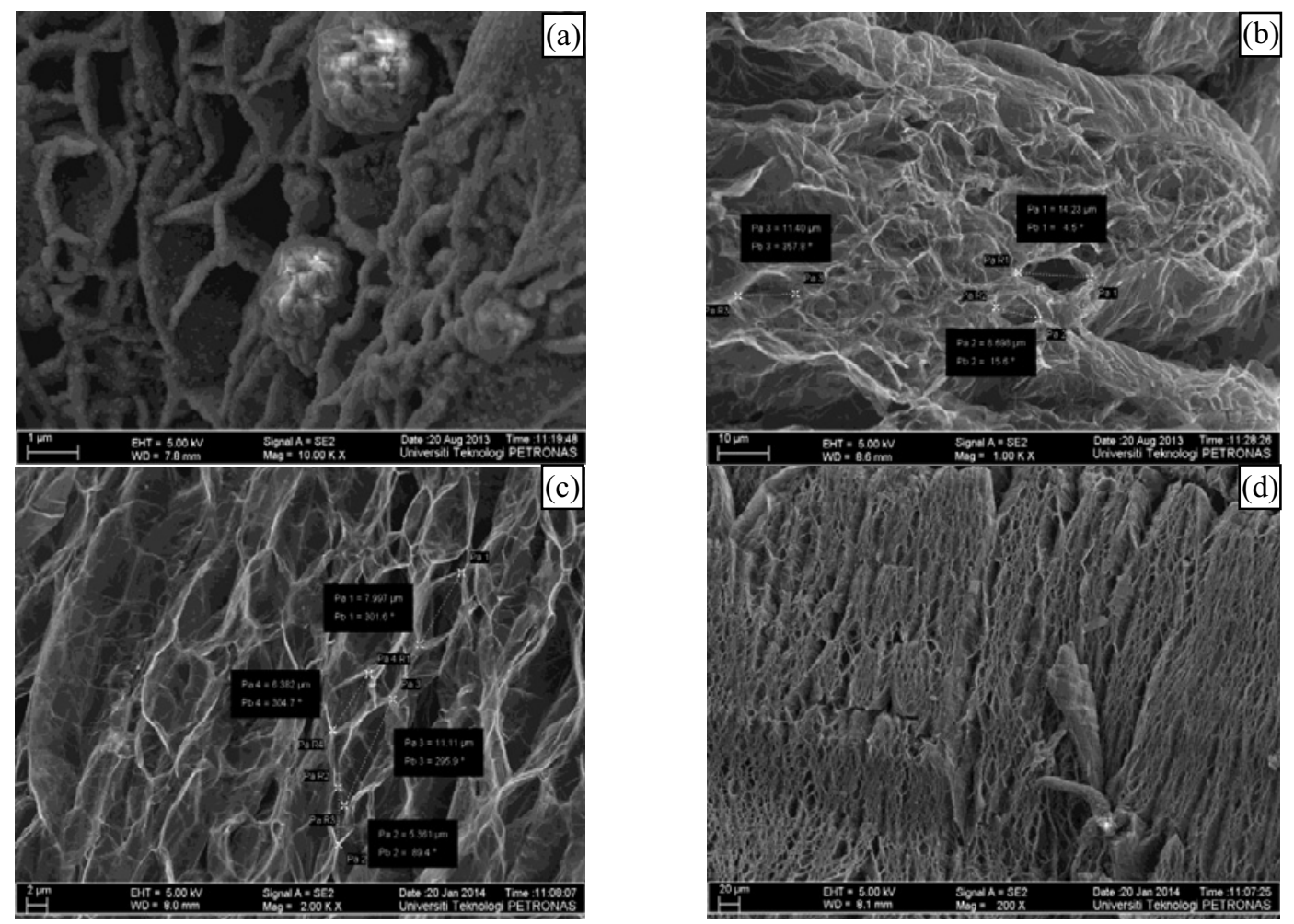

Figure1. FESEM images for IFRC's for (a) IFR4 filler particle size $44 \mu \mathrm{m}$ (b) formulation IFR5 filler particle size $44 \mu \mathrm{m}$ (c) IFR4 filler particle size $10 \mu \mathrm{m}$ (d) IFR5 particle size $10 \mu \mathrm{m}$ 


\subsection{EDX Analysis}

EDX analysis was performed to determine the presence of element in char. EDX images are shown in Figure2.
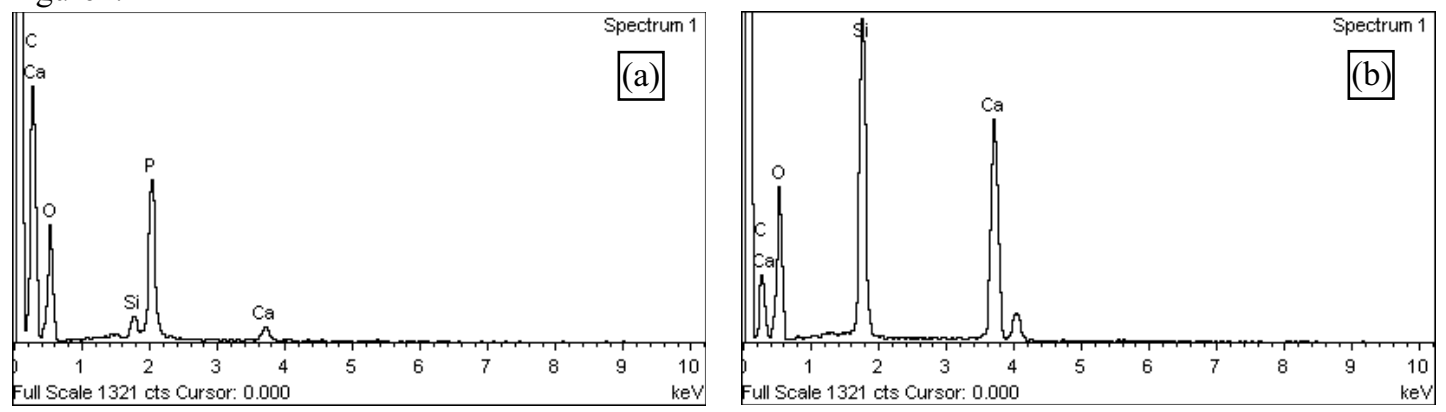

Figure2. EDX images for formulations (a) IFR4 of particle size $44 \mu \mathrm{m}$ (b) Wollastonite filler

\subsection{XRD}

Char left behind after furnace test is subjected to XRD analysis. XRD determines composition of the char. Measurements are done on a diffractometer Bruker AXS D8 Advance using $\mathrm{Cu} \mathrm{K \alpha}$ radiation and a nickel filter $(\mathrm{k}=0.150595 \mathrm{~nm})$ in the range $\left(10^{\circ}<2 \theta<90^{\circ}\right)$. All peak values were allotted according to JCPDS card. Elements with large quantity present in the sample shows prominent peaks. The peak at 3.61753 showed boron phosphate. Peak at 3.34045 was allocated to calcium borate phosphate. In Figure3(b) peak 3.35948 was allotted to graphite. Graphite was present in large amount in residue because of EG. XRD results showed boric acid, melamine APP, O2 and Wollastonite on reacted with each other and developed the char. Boric acid in the char is transformed into boron oxide and boron oxide reacted with APP and final product boron phosphate was formed and stability of boron has been reported very much even at $1200^{\circ} \mathrm{C}[11]$.
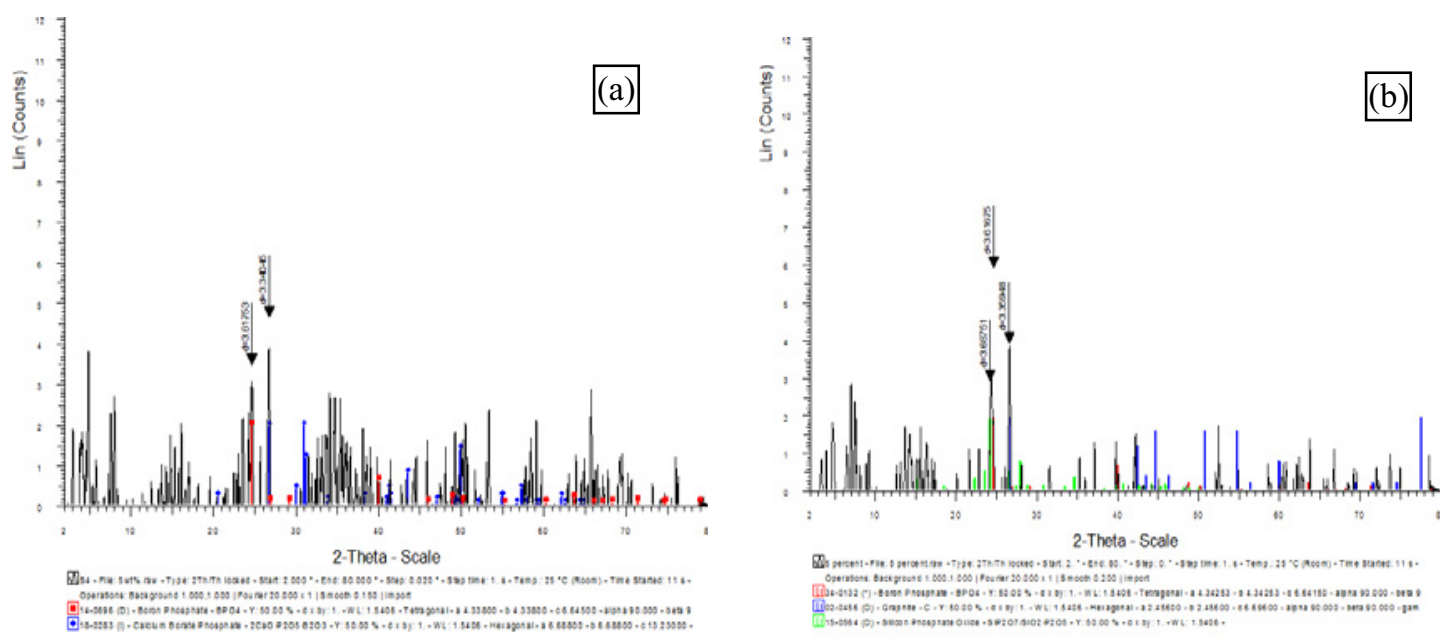

Figure3. XRD images for formulation (a) IFR5 of filler particle size $10 \mu \mathrm{m}$ (b) IFR5 of filler particle size $44 \mu \mathrm{m}$ 


\section{Conclusion}

IFRC's containing $10 \mu \mathrm{m}$ particle size of Wollastonite filler gave lower back side steel temperature than Wollastonite filler of particle size $44 \mu \mathrm{m}$. Furnace test result that IFRC's of smaller Wollastonite filler particle size showed better expansion due to large pores developed during combustions which enhanced thermal performance of IFRC's. Presence silicon phosphate oxide, boron phosphate and calcium phosphate oxide improved the thermal stability of the char.

\section{Acknowledgment}

Authors are like to acknowledge the financial support provided by Universiti Teknologi PETRONAS for this research.

\section{References}

1. M. Jimenez, S. Duquesne, and S. Bourbigot, Proceedings of the COMSOL Multiphysics User's Conf., (2005)

2. S. Duquesne, S. Magnet, C. Jama, and R. Delobel, Surf. and Coat. Technol., 180, pp. 302-307,( 2004)

3. R. Krishnamoorthy and C. Bailey, (2009)

4. J. Rhys, Fire and Materials, 4, pp. 154-156, (1980)

5. R. Otáhal, D. Veselý, J. Násadová, V. Zíma, P. Nemec, and P. Kalenda, Pigm. Resin Technol., 40, pp. 247-253, (2011)

6. S. Duquesne, S. Magnet, C. Jama, and R. Delobel, Surf. and Coat. Technol, 180-181, pp. 302307, (2004)

7. S. Bourbigot, M. Le Bras, R. Delobel, P. Bréant, and J.-M. Tremillon, Polym. Degrad. Stab., 54, pp. 275-287, (1996)

8. G. Camino, L. Costa, and G. Martinasso, Polym. Degrad. Stab., 23, pp. 359-376, (1989)

9. R. Hadal, A. Dasari, J. Rohrmann, and R. Misra, Mater. Sci. Eng.: A, 372, pp. 296-315, (2004)

10. S. Hamdani-Devarennes, A. Pommier, C. Longuet, J.-M. Lopez-Cuesta, and F. Ganachaud, Polym. Degrad. Stab., 96, pp. 1562-1572, (2011)

11. A. Luyt, M. Dramićanin, Z. Antić, and V. Djoković, Polym. testing, 28, pp. 348-356, (2009)

12. Y. T. H. Quach, L. Ferry, R. Sonnier, and J. M. Lopez Cuesta, Polym. Adv. Technol., 24, pp. 104-113, (2013) 